\title{
Determinan Profitabilitas Dengan Ukuran Perusahaan Sebagai Variabel Moderasi
}

\section{Determinants of Profitability with Firm Size as Moderation Variable}

\author{
Eny Maryanti* \\ Universitas Muhammadiyah Sidaorjo, Indonesia
}

OPEN ACCESS

ISSN 2548-3501 (online)

Edited by:

Wiwit Hariyanto

Reviewed by:

Riski A.N

${ }^{*}$ Correspondence:

Eny Maryanti

enymaryanti@umsida.ac.id

Received: 06 Mei 2020

Accepted: 15 Juli 2020

Published: 31 Juli 2020

Citation:

Maryanti E (2020) Determinan Profitabilitas Dengan Ukuran

Perusahaan Sebagai Variabel

Moderasi.

Journal of accounting Science. 4:2.

doi: 10.21070/jas.v4i2.1099
This study aims to determine whether company size moderates the effect of current ratio, environmental performance and debt to equity ratio on the profitability of consumer goods industry companies found on the Indonesia Stock Exchange (IDX). The period of this research is 2017-2019. The study population includes all consumer goods industry companies found on the Indonesia Stock Exchange (IDX) for the period of 2017-2019. The sampling technique used was purposive sampling. The research population data were 114 companies and obtained a sample of 45 companies. The data analysis method used is SmartPLS 3 (Partial Least Square). The results of this study indicate: company size can moderate the effect of current ratio, environmental performance and debt to equity ratio to profitability, firm size weakens the influence of current ratio to profitability, company size weakens the influence of environmental performance on profitability, firm size weakens the influence of debt to equity ratio to profitability. The moderation variable in this study is included in the pure moderation variable (pure moderation) because the moderating effect 1,2,3 has an effect on profitability while the moderating variable (company size) has no effect on profitability.

Keywords: current ratio, environmental performance, debt to equity ratio, profitability, company size

Penelitian ini bertujuan untuk mengetahui apakah ukuran perusahaan memoderasi pengaruh current ratio, kinerja lingkungan dan debt to equity ratio pada profitabilitas perusahaan consumer goods industry yang terdapat pada Bursa Efek Indonesia (BEI). Periode penelitian ini adalah tahun 2017-2019. Populasi penelitian meliputi semua perusahaan consumer goods industry yang terdapat pada Bursa Efek Indonesia (BEI) periode 2017-2019. Teknik pengambilan sampel yang digunakan adalah purposive sampling. Data populasi penelitian sebanyak 114 perusahaan, dan diperoleh sampel sebanyak 45 perusahaan. Metode analisis data yang digunakan adalah SmartPLS 3 (Partial Least Square). Hasil penelitian ini menunjukkan : ukuran perusahaan dapat memoderasi pengaruh current ratio dan debt to equiy ratio terhadap profitabilitas, ukuran perusahaan memperlemah pengaruh antara current ratio terhadap profitabilitas, ukuran perusahaan memperlemah pengaruh antara kinerja lingkungan terhadap profitabilitas, ukuran perusahaan memperlemah pengaruh antara debt to equity ratio terhadap profitabilitas. Variabel moderasi dalam penelitian ini termasuk dalam variabel moderasi murni (pure moderasi) 
karena moderating effect 1,2,3 berpengaruh terhadap profitabilitas sedangkan variabel moderasi (ukuran perusahaan) tidak berpengaruh terhadap profitabilitas

Keywords: current ratio, environmental performance, debt to equity ratio, profitability, company size 


\section{PENDAHULUAN}

Dalam dunia bisnis, profitabilitas menjalankan peran penting dalam struktur maupun perkembangan perusahaan dengan mempengaruhi pengambilan keputusan karena dapat mengukur kinerja dan menilai sejauh mana perusahaan dapat menghasilkan laba. Menurut Setiawan (2019) profitabilitas merupakan salah satu indikator yang penting untuk menilai suatu perusahaan. Selain digunakan untuk mengukur kemampuan perusahaan dalam menghasilkan laba juga untuk mengetahui efektifitas perusahaan dalam mengelola sumber-sumber yang dimilikinya. Menurut Fahmi (2011) semakin baik rasio profitabilitas maka semakin baik menggambarkan kemampuan tingginya perolehan keuntungan perusahaan.

Agar perusahaan dapat memaksimalkan keuntungan perusahaan, maka manajer keuangan perusahaan harus mengetahui apa saja faktor-faktor yang mempengaruhi profitabilitas, karena setiap faktor yang terdapat di dalam perusahaan memiliki pengaruh yang berbeda-beda dalam menghasilkan laba. Adapun faktor-faktor yang mempengaruhi profitabilitas perusahaan adalah current ratio, kinerja lingkungan dan debt to equity ratio. Faktor yang pertama yaitu current ratio adalah rasio likuiditas yang digunakan untuk mengukur kemampuan perusahaan dalam memenuhi kewajibannya Mahardhika and Marbun (2016). Sebelumnya sudah dilakukan penelitian mengenai pengaruh current ratio terhadap profitabilitas, namun hasil dari penelitian yang dilakukan oleh peneliti terdahulu menunjukkan adanya ketidakkonsistenan hasil penelitian. Menurut Sofie (2015) current ratio memiliki pengaruh signifikan positif terhadap profitabilitas. Hal ini berbeda dengan hasil penelitian yang dilakukan oleh Sandi (2017) yang menunjukkan bahwa current ratio tidak berpengaruh terhadap profitabilitas

Faktor berikutnya yaitu debt to equity ratio adalah suatu rasio keuangan yang menunjukkan proporsi relatif antara ekuitas dan hutang yang digunakan untuk membiayai aset perusahaan Kho (2017). Sebelumnya sudah dilakukan penelitian mengenai pengaruh debt to equity ratio terhadap profitabilitas, namun hasil dari penelitian yang dilakukan oleh peneliti terdahulu menunjukkan adanya ketidakkonsistenan hasil penelitian. Menurut Pebrianti (2018) debt to equity ratio tidak berpengaruh terhadap profitabilitas. Hal ini berbeda dengan penelitian yang dilakukan oleh Hantono (2015) menunjukkan bahwa DER berpengaruh signifikan terhadap profitabilitas.

kinerja lingkungan maka dapat membantu perusahaan dalam mencapai tujuan perusahaan dan memenuhi tanggung jawab kepada stakeholder perusahaan. Perusahaan dikatakan memiliki kepedulian yang baik apabila perusahaan ikut serta dalam menjaga lingkungan hidup dan konservasinya. Hal tersebut harus diikuti dengan pelaporan akuntansi lingkungan yang ada di perusahaan. Sebelumnya sudah dilakukan penelitian mengenai pengaruh kinerja lingkungan terhadap profitabilitas, namun hasil dari penelitian yang dilakukan oleh peneliti terdahulu menunjukkan adanya ketidakkonsistenan hasil penelitian. Menurut Sulistiawati and Dirgantari (2016) kinerja lingkungan berpengaruh terhadap profitabilitas.

Dari beberapa penelitian yang dilakukan sebelumnya tentang pengaruh current ratio, kinerja lingkungan dan debt to equity ratio terhadap profitabilitas dapat diketahui adanya ketidakkonsistenan dari hasil penelitian yang dilakukan sebelumnya. Hal ini membuat peneliti menduga adanya variabel yang dapat memperlemah atau memperkuat current ratio, kinerja lingkungan dan debt to equity ratio terhadap profitabilitas yaitu ukuran perusahaan. Karena itu peneliti menggunakan ukuran perusahaan sebagai variabel moderasi pengaruh current ratio, kinerja lingkungan dan debt to equity ratio terhadap profitabilitas. Hal ini diperkuat dengan adanya penelitian yang dilakukan oleh Dahuna (2016) yang menyatakan bahwa ukuran perusahaan dapat memoderasi pengaruh current ratio terhadap profitabilitas, penelitian yang dilakukan oleh Twindita (2015) yang menyatakan bahwa ukuran perusahaan bukan merupakan variabel moderasi antara hubungan kinerja lingkungan terhadap profitabilitas dan penelitian yang dilakukan oleh oleh Basri and Dahrani (2017) yang menyatakan bahwa ukuran perusahaan mempengaruhi hubungan DER dan LDER terhadap ROE.

\section{METODE}

Penelitian ini dilakukan pada perusahaan Consumer Goods Industry yang terdaftar di BEI pada tahun 2017-2019. Data diambil dari situs resmi BEI yaitu (www.idx.co.id) berupa laporan keuangan tahun dan annual report tahun 2017-2019.

Populasi dalam penelitian ini adalah perusahaan Consumer Goods Industry yang terdaftar di BEI pada tahun 2017 - 2019 yang berjumlah 114 perusahaan. Sampel dalam penelitian ini menggunakan metode non probability sampling dengan menggunakan teknik purposive sampling. Yaitu teknik pengambilan sampel dilakukan dengan pertimbangan atau kriteria tertentu Sugiyono (2011)Kriteria tersebut terdapat pada Tabel 1

\section{[Table 1 about here.]}

Untuk pengukuran variabel atau indikator terdapat pada Tabel 2

[Table 2 about here.]

\section{Metode Analisis Data}

Teknik analisis yang digunakan dalam penelitian ini menggunakan Uji Partial Least Square (PLS) Abdillah and Jogiyanto (2015) menjelaskan bahwa PLS adalah metode analisis yang bersifat soft modeling karena tidak mengasumsikan data harus dengan pengukuran skala tertentu, yang berarti jumlah dapat kecil (di bawah 100 sampel).

\section{HASIL DAN PEMBAHASAN}

\section{[Figure 1 about here.]}


Dari gambar Gambar 1loading factor untuk masingmasing indikator cukup reliable dengan nilai seluruh indikator diatas 0.50. Sehingga semua indikator sudah valid dan tidak ada nilai yang menunjukkan dibawah 0.50 .

\section{Evaluasi Model Struktural (Inner Model)}

[Table 3 about here.]

Nilai R-Square sebesar 0.537 pada Tabel 3 berarti validitas konstruk profitabilitas yang dapat dijelaskan oleh konstruk current ratio, konstruk kinerja lingkungan, konstruk DER dan interaksinya sebesar 53,7 \% sedangkan 46,3\% dijelaskan oleh variabel lain yang tidak terdapat dalam penelitian ini.

Pengujian hipotesis dilakukan dengan membandingkan nilai $\mathrm{T}$ value dengan $\mathrm{T}$ tabel. Adapun hasil Path Coefficients dan uji signifikansi pada Tabel 4 adalah sebagai berikut :

\section{[Table 4 about here.]}

Uji hubungan antar konstruk menunjukkan bahwa konstruk moderating effect 1 (konstruk interaksi antara current ratio dan ukuran perusahaan) mampu mempengaruhi profitabilitas dengan signifikan pada $5 \%$ (T statistic $3.308>1.96$ ) dan nilai $P$ value sebesar 0.001 sehingga $P$ Value $<0.05$ dengan demikian dapat disimpulkan bahwa current ratio yang dimoderasi oleh ukuran perusahan berpengaruh signifikan terhadap profitabilitas.

Konstruk moderating effect 2 (konstruk interaksi antara kinerja lingkungan dan ukuran perusahaan) mampu mempengaruhi profitabilitas dengan signifikan pada $5 \%$ (T statistic $2.916>1.96)$ dan nilai $\mathrm{P}$ Value sebesar 0.004 sehingga $\mathrm{P}$ Value $<0.05$ dengan demikian dapat disimpulkan bahwa kinerja lingkungan yang dimoderasi oleh ukuran perusahan berpengaruh signifikan terhadap profitabilitas.

Konstruk moderating effect 3 (konstruk interaksi antara debt to equity ratio dan ukuran perusahaan) mampu mempengaruhi profitabilitas dengan signifikan pada $5 \%$ (T statistic $2.254>1.96)$ dan nilai $\mathrm{P}$ Value sebesar 0.025 sehingga $\mathrm{P}$ Value $<0.05$ dengan demikian dapat disimpulkan bahwa DER yang dimoderasi oleh ukuran perusahan berpengaruh signifikan terhadap profitabilitas.

Dan untuk konstruk ukuran perusahaan tidak dapat mempengaruhi profitabilitas karena nilai $\mathrm{T}$ statistic sebesar 1.153 kurang dari 1.96 dan nilai $P$ value sebesar 0.250 kurang dari 0.05 .

\section{PEMBAHASAN}

Pengujian hipotesis : Ukuran perusahaan memoderasi pengaruh current ratio, kinerja lingkungan dan debt to equiy ratio terhadap profitabilitas perusahaan consumer goods industry yang terdaftar di BEI. Hasil analisis yang dilakukan dengan menggunakan smartPLS dapat dilihat pada tabel 4.8 yang menunjukkan hasil bahwa ukuran perusahaan dapat memoderasi pengaruh current ratio, kinerja lingkungan dan debt to equiy ratio terhadap profitabilitas perusahaan consumer goods industry yang terdaftar di BEI.

Pengaruh current ratio terhadap profitabilitas dengan ukuran perusahaan sebagai variabel moderasi. Dari tabel 4.8 dapat diketahui bahwa uji hubungan antar konstruk menunjukkan bahwa konstruk moderating effect 1 (konstruk interaksi antara current ratio dan ukuran perusahaan) mampu mempengaruhi profitabilitas dengan signifikan pada 5\% (T statistic $3.308>$ 1.96) dan nilai $P$ value sebesar 0.001 sehingga $P$ Value $<0.05$ sehingga hasil dari penelitian ini menunjukkan bahwa ukuran perusahaan mampu memoderasi variabel current ratio terhadap profitabilitas secara signifikan. Variabel moderasi effect 1 dalam penelitian ini termasuk dalam variabel moderasi murni (pure moderasi) karena moderating effect 1 berpengaruh terhadap profitabilitas sedangkan variabel moderasi (ukuran perusahaan) tidak berpengaruh terhadap profitabilitas Bryan and Haryadi (2018). Koefisien regresi variabel pemoderasi antara current ratio dan ukuran perusahaan sebesar -0.887 yang menunjukkan hubungan yang negatif. Sehingga, dapat disimpulkan bahwa ukuran perusahaan memperlemah pengaruh antara current ratio terhadap profitabilitas.

Ukuran perusahaan memperlemah pengaruh current ratio terhadap profitabilitas. Karena semakin besar aset yang dimiliki oleh perusahaan maka semakin besar ukuran perusahaan tersebut dan juga semakin besar modal yang ditanam dalam perusahaan Dahuna (2016) . Perusahaan yang memiliki lebih banyak sumber-sumber aset yang dapat dikonversi menjadi kas yang berasal dari laba perusahaan dapat diinterpretasikan bahwa memiliki current ratio yang tinggi. Nilai current ratio yang tinggi dari suatu perusahaan akan mengurangi ketidakpastian bagi investor, namun mengindikasikan adanya dana yang menganggur (idle cash) sehingga akan mengurangi tingkat profitabilitas perusahaan, akibatnya EPS juga semakin kecil. Hasil dari penelitian ini sesuai dengan penelitian yang dilakukan oleh Dahuna (2016) yang menyatakan bahwa variabel size dapat memoderasi pengaruh likuiditas (current ratio) terhadap profitabilitas.

Pengaruh kinerja lingkungan terhadap profitabilitas dengan ukuran perusahaan sebagai variabel moderasi. Uji hubungan antar konstruk menunjukkan bahwa konstruk moderating effect 2 (konstruk interaksi antara kinerja lingkungan dan ukuran perusahaan) mampu mempengaruhi profitabilitas dengan signifikan pada 5\% (T statistic $2.916>1.96$ ) dan nilai $\mathrm{P}$ Value sebesar 0.004 sehingga $\mathrm{P}$ Value $<0.05$ sehingga hasil dari penelitian ini menunjukkan bahwa ukuran perusahaan mampu memoderasi variabel kinerja lingkungan terhadap profitabilitas secara signifikan. Variabel moderasi effect 2 dalam penelitian ini termasuk dalam variabel moderasi murni (pure moderasi) karena moderating effect 2 berpengaruh terhadap profitabilitas sedangkan variabel moderasi (ukuran perusahaan) tidak berpengaruh terhadap profitabilitas Bryan and Haryadi (2018) . Koefisien regresi variabel pemoderasi antara kinerja lingkungan dan ukuran perusahaan sebesar 0.458 yang menunjukkan hubungan yang negatif. Sehingga, dapat disimpulkan bahwa ukuran perusahaan memperlemah 
pengaruh antara kinerja lingkungan terhadap profitabilitas.

Besar kecilnya perusahaan yang mengikuti PROPER tidak dapat mempengaruhi perusahaan dalam meningkatkan profitabilitas. Perusahaan yang menganggarkan sejumlah dana untuk melakukan program lingkungan perusahaan, tidak akan mencerminkan kinerja lingkungan yang baik juga. Tidak ada jaminan yang kuat bahwa dana lingkungan yang besar, besar pula program dan juga dampak dari pelaksanaan program lingkungan tersebut dalam meningkatkan profitabilitas perusahaan. Hasil dari penelitian ini tidak sesuai dengan penelitian yang dilakukan oleh Twindita (2015) yang menyatakan bahwa ukuran perusahaan bukan merupakan variabel moderasi antara hubungan kinerja lingkungan terhadap profitabilitas.

Pengaruh debt to equity ratio terhadap profitabilitas dengan ukuran perusahaan sebagai variabel moderasi. Uji hubungan antar konstruk menunjukkan bahwa konstruk moderating effect 3 (konstruk interaksi antara debt to equity ratio dan ukuran perusahaan) mampu mempengaruhi profitabilitas dengan signifikan pada $5 \%$ (T statistic $2.254>1.96$ ) dan nilai $\mathrm{P}$ Value sebesar 0.025 sehingga $\mathrm{P}$ Value $<0.05$ sehingga hasil dari penelitian ini menunjukkan bahwa ukuran perusahaan mampu memoderasi variabel debt to equity ratio terhadap profitabilitas secara signifikan. Variabel moderasi effect 3 dalam penelitian ini termasuk dalam variabel moderasi murni (pure moderasi) karena moderating effect 3 berpengaruh terhadap profitabilitas sedangkan variabel moderasi (ukuran perusahaan) tidak berpengaruh terhadap profitabilitas Bryan and Haryadi (2018) . Koefisien regresi variabel pemoderasi antara debt to equity ratio dan ukuran perusahaan sebesar -0.437 yang menunjukkan hubungan yang negatif. Sehingga, dapat disimpulkan bahwa ukuran perusahaan memperlemah pengaruh antara debt to equity ratio terhadap profitabilitas.

Hasil penelitian ini menunjukkan bahwa ukuran perusahaan memperlemah pengaruh DER terhadap profitabilitas. Lauterbach (1999) menyatakan bahwa semakin besar total aktiva yang dimiliki oleh perusahaan, maka kecenderungan perusahaan untuk melakukan pinjaman guna membiayai kegiatannya semakin menurun karena perusahaan memiliki sejumlah dana untuk membiayai kegiatan oprasionalnya. Semakin besar ukuran perusahaan akan mencerminkan pula kemampuan perusahaan untuk dapat mempertahankan keuntungannya, sehingga perusahaan akan lebih sedikit menggunakan hutang sebagai pembiayaan karena dalam laporan rugi laba, salah satu akun adalah mencakup biaya bunga yang merupakan beban keuangan perusahaan atas hutang yang dimiliki perusahaan. Dengan demikian maka posisi hutang yang lebih besar juga menjadi faktor yang meningkatkan biaya operasional perusahaan yang dapat menurunkan laba bersih perusahaan.

Hasil dari penelitian ini sesuai dengan penelitian yang dilakukan oleh Basri and Dahrani (2017) yang menyatakan bahwa ukuran perusahaan mempengaruhi hubungan antara debt to equity ratio terhadap return on equity. Namun, Hasil penelitian ini berbeda dengan penelitian yang dilakukan oleh Dahuna (2016) yang menyatakan bahwa variabel size tidak dapat memoderasi pengaruh leverage terhadap profitabilitas

Jadi dapat disimpulkan, bahwa terjadi hubungan moderasi yaitu moderasi murni (pure moderator) karena moderating effect 1,2,3 berpengaruh terhadap profitabilitas sedangkan variabel moderasi (ukuran perusahaan) tidak berpengaruh terhadap profitabilitas. Pure moderasi merupakan variabel yang memoderasi hubungan antara variabel independen dan variabel dependen di mana variabel moderasi murni berinteraksi dengan variabel independen tanpa menjadi variabel independent Bryan and Haryadi (2018).

\section{KESIMPULAN}

Berdasarkan pembahasan hasil penelitian yang telah diuraikan, maka dapat disimpulkan bahwa ukuran perusahaan dapat memoderasi pengaruh current ratio, kinerja lingkungan dan debt to equiy ratio terhadap profitabilitas, ukuran perusahaan memperlemah pengaruh current ratio, kinerja lingkungan dan debt to equiy ratio terhadap profitabilitas perusahaan consumer goods industry yang terdaftar di BEI tahun 20172019. Variabel moderasi dalam penelitian ini termasuk dalam variabel moderasi murni (pure moderasi) karena moderating effect 1,2,3 berpengaruh terhadap profitabilitas sedangkan variabel moderasi (ukuran perusahaan) tidak berpengaruh terhadap profitabilitas. Koefisien regresi variabel pemoderasi antara current ratio dan ukuran perusahaan sebesar -0.887 yang menunjukkan hubungan yang negatif. Sehingga, dapat disimpulkan bahwa ukuran perusahaan memperlemah pengaruh antara current ratio terhadap profitabilitas. Variabel moderasi effect 2 dalam penelitian ini termasuk dalam variabel moderasi murni (pure moderasi) karena moderating effect 2 berpengaruh terhadap profitabilitas sedangkan variabel moderasi (ukuran perusahaan) tidak berpengaruh terhadap profitabilitas Bryan and Haryadi (2018). Koefisien regresi variabel pemoderasi antara kinerja lingkungan dan ukuran perusahaan sebesar -0.458 yang menunjukkan hubungan yang negatif. Variabel moderasi effect 3 dalam penelitian ini termasuk dalam variabel moderasi murni (pure moderasi) karena moderating effect 3 berpengaruh terhadap profitabilitas sedangkan variabel moderasi (ukuran perusahaan) tidak berpengaruh terhadap profitabilitas Bryan and Haryadi (2018) . Koefisien regresi variabel pemoderasi antara debt to equity ratio dan ukuran perusahaan sebesar -0.437 yang menunjukkan hubungan yang negatif. Sehingga, dapat disimpulkan bahwa ukuran perusahaan memperlemah pengaruh antara debt to equity ratio terhadap profitabilitas

\section{UCAPAN TERIMA KASIH}

Peneliti mengucapkan terima kasih kepada seluruh pihak yang telah membantu penelitian ini. 


\section{REFERENCES}

Abdillah, W. and Jogiyanto (2015). Partial Least Square (PLS) (Bengkulu: Andi). Basri, M. and Dahrani (2017). Efek Moderasi Ukuran Perusahaan Pada Pengaruh Debt To Equity Ratio Dan Longterm Debt To Equity Ratio Terhadap ROE Di Bursa Efek Indonesia. Jurnal Riset Financsal Bisnis 1, 65-78.

Bryan, B. and Haryadi, E. (2018). Analisis Pengaruh Variabel Moderasi Switching Costs Terhadap Hubungan Service Performance dan Customer Loyalty Member Celebrity Fitness Jakarta. doi: 10.25170/jm.v15i1.98. https://dx.doi.org/10. 25170/jm.v15i1.98.

Dahuna, D. (2016). Pengaruh WCT, Likuiditas, Dan Leverage Terhadap Profitabilitas Dengan Size Sebagai Variabel Moderating.

Fahmi, I. (2011). Analisis Laporan Keuangan., and others (ed.) (Alfabeta).

Haholongan, R. (2016). Kinerja Lingkungan dan Kinerja Ekonomi Perusahaan Manufaktur Go Public. Jurnal Ekonomi dan Bisnis 19, 413-413. doi: 10.24914/ jeb.v19i3.477.

Hantono (2015). Pengaruh Current Ratio Dan Debt To Equity Ratio Terhadap Profitabilitas Pada Perusahaan Manufaktur Sektor Logam Dan Sejenisnya Yang Terdaftar Di Bursa Efek Indonesia Periode. Jurnal Wira Ekonomi Mikroskil V, 21-29.

Kasmir (2009). Pengantar manajemen keuangan., and others (ed.) (Jakarta: Pranada Media).

Kho, B. (2017). Ilmu Manajemen Industri.

Lauterbach, V. (1999). Ownership Structure and Firm Performance: Evidance From Israel. Journal Of Management and Governance 3, 189-201.

Mahardhika, P. A. and Marbun, D. (2016). Pengaruh Current Ratio Dan Debt To Equity Ratio Terhadap Return On Assets. Jurnal Widyakala 3.

Pebrianti, Y. (2018). Pengaruh Debt To Asset Ratio (Dar) Dan Debt To Equity Ratio (Der) Terhadap Profitabilitas Perusahaan Indeks Lq 45 Bursa Efek Indonesia. Jurnal Ilmu Pengetahuan Discovery 4.
Samsul, M. (2008). Pasar Modal Dan Manajemen Portofolio (Jakarta: jakarta).

Sandi, D. K. (2017). Pengaruh Intellectualcapital, Current Ratio Dan Total Asset Turnover Terhadap Profitabilitas. Journal of Chemical Information and Modeling $53,1689-1699$.

Setiawan, P. (2019). Pengertian Rasio Profitabilitas Menurut Para Ahli. Guru Pendidikan. . Retrieved from www.gurupendidikan.

Sofie, B. A. N. (2015). PENGARUH STRUKTUR MODAL DAN LIKUIDITAS TERHADAP PROFITABILITAS. Jurnal Akuntansi Trisakti 2, 13-13. doi: 10.25105/jat.v2i1.4829.

Sugiyono (2011). Metode Penelitian Bisnis (Pendekatan Kuantitatif (Bandung: Alfabeta.).

Sulistiawati, E. and Dirgantari, N. (2016). Analisis Pengaruh Penerapan Green Accounting Terhadap Profitabilitas Pada Perusahaan Pertambangan Yang Terdaftar Di Bursa Efek Indonesia. Jurnal Reviu Akuntansi dan Keuangan 6, $865-872$.

Twindita, M. F. (2015). Pengaruh Kinerja Lingkungan, Pengungkapan Tanggung Jawab Sosial Perusahaan terhadap Profitabilitas Perusahaan dengan Ukuran Perusahaan sebagai Variabel Moderasi. Jurnal Ilmiah Universitas Brawijaya 5.

Conflict of Interest Statement: The author declare that the research was conducted in the absence of any commercial or financial relationships that could be construed as a potential conflict of interest.

Copyright $\odot 2020$ Maryanti. This is an open-access article distributed under the terms of the Creative Commons Attribution License (CC BY). The use, distribution or reproduction in other forums is permitted, provided the original author(s) and the copyright owner(s) are credited and that the original publication in this journal is cited, in accordance with accepted academic practice. No use, distribution or reproduction is permitted which does not comply with these terms. 


\section{LIST OF TABLES}

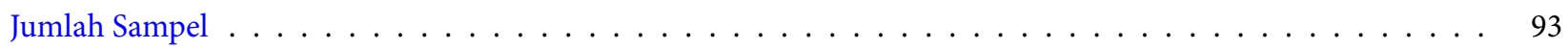

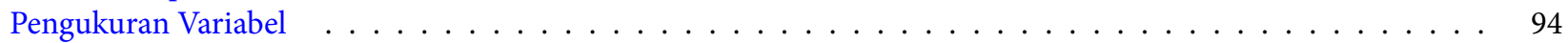

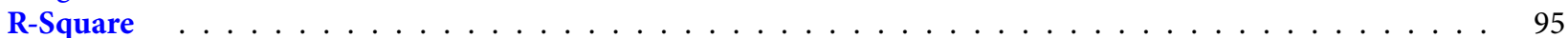

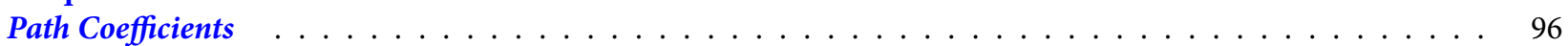


TABLE 1 | Jumlah Sampel

Perusahaan Consumer Goods Industry yang terdaftar di BEl pada tahun 2017-2019

Perusahaan Consumer Goods Industry yang menerbitkan laporan keuangan yang lengkap dan jelas pada tahun 2016-2018 secara berturut-turut

Perusahaan yang menyajikan Laporan keuangan dalam mata uang rupiah

Perusahaan yang tidak mengalami kerugian selama tahun pengamatan pada tahun 2016-2018 
TABLE 2 | Pengukuran Variabel

$\begin{array}{ll}\text { Variabel } & \text { Indikator } \\ \text { Profitabilitas (Y) } & \text { EPS : } \\ & \text { (Laba Bersih -deviden saham preveren) :Jumlah saham yang beredar } \\ & \text { Sumber: Kasmir (2009); Fahmi (2011) } \\ & \text { Current ratio : Aktiva lancar Hutang lancar } \\ \text { Current Ratio } & \text { Sumber : Samsul (2008) } \\ (\text { X1) } & \text { Kinerja lingkungan (PROPER) } \\ \text { Kinerja Lingkungan } & \text { Sumber: Haholongan (2016) } \\ \text { (X2) } & \text { DER : } \\ \text { Debt to Equity Ratio } & \text { Total Hutang Total Ekuitas (Modal) } \\ \text { (X3) } & \text { Sumber : Fahmi (2011) } \\ & \text { Ukuran perusahaan }=\text { Log n (total aset) } \\ \text { Ukuran Perusahaan (Z) } & \text { Sumber : Hantono (2015) } \\ \end{array}$


TABLE 3 | R-Square

R-Square

Profitabilitas

0.537 
TABLE 4 | Path Coefficients

\begin{tabular}{|c|c|c|c|c|c|}
\hline & Original sample (O) & Sample Mean (M) & Standart Error (STERR) & T Statistics (O/STERR) & P Value \\
\hline CR-> Profitabilitas & -0.755 & -0.826 & 0.302 & 2.502 & 0.013 \\
\hline DER-> Profitabilitas & -0.287 & -0.310 & 0.225 & 1.274 & 0.203 \\
\hline Efek moderasi 1 -> Profitabilitas & -0.887 & -0.965 & 0.268 & 3.308 & 0.001 \\
\hline Efek moderasi 2 -> Profitabilitas & -0.458 & -0.504 & 0.157 & 2.916 & 0.004 \\
\hline Efek moderasi 3 -> Profitabilitas & -0.437 & -0.461 & 0.194 & 2.254 & 0.025 \\
\hline KL -> Profitabilitas & -0.035 & -0.021 & 0.152 & 0.230 & 0.818 \\
\hline Ukuran perusahaan -> Profitabilitas & 0.198 & 0.171 & 0.171 & 1.153 & 0.250 \\
\hline
\end{tabular}




\section{LIST OF FIGURES}

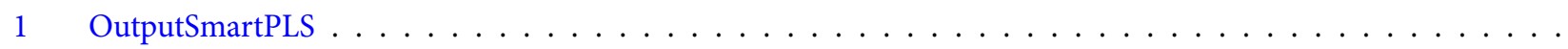




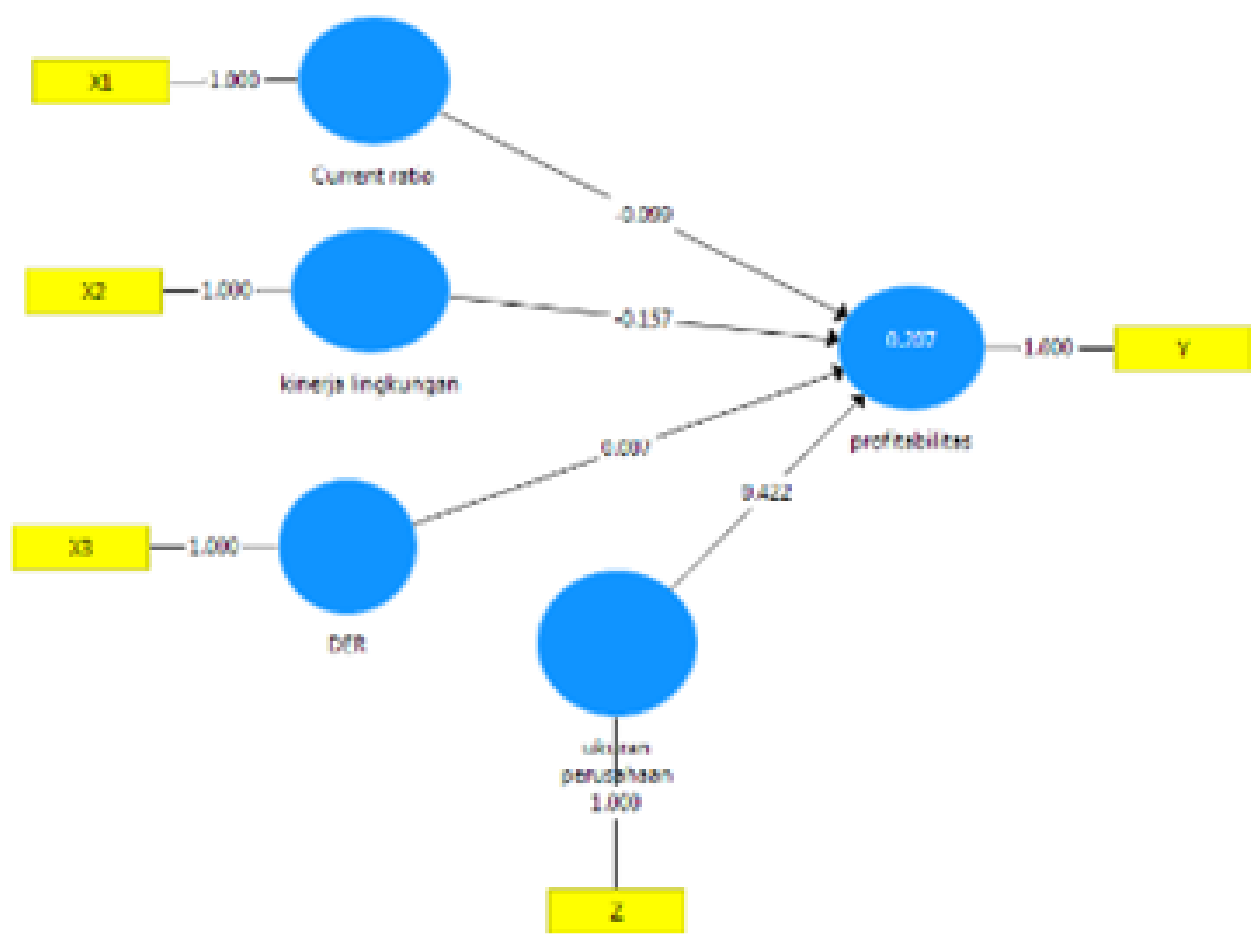

FIGURE 1 | OutputSmartPLS 